\title{
ENTREPRENEURIAL ORIENTATION IN SUPPLY CHAIN MANAGEMENT: A SYSTEMATIC REVIEW
}

\author{
Andres Felipe Cortes \\ Sacred Heart University, USA \\ Email: cortesortiza@sacredheart.edu \\ Younggeun Lee \\ California State University, Los Angeles, USA \\ Email: ylee16@,calstatela.edu \\ Juan David Cortes \\ Providence College, USA \\ Email: $\underline{\text { david.cortes@providence.edu }}$ \\ Isidro Liñan \\ Iowa State University, USA \\ Email: isidro@iastate.edu
}

Received: 26 March 2021. Revision received: 28 April 2021. Accepted: 9 June 2021

\begin{abstract}
Companies around the world need to reconcile the need to differentiate their offerings and remain entrepreneurial in a competitive environment while also running extremely efficient and effective operations. Surprisingly, however, limited studies have provided a synthesis and overview of existing research exploring important links between the entrepreneurship and supply chain management (SCM) fields. In this paper, we aim to address this issue by developing a systematic review of research exploring the link between entrepreneurial orientation (EO) and SCM, while synthesizing the most relevant findings in this intersection. We also aim to promote the development of this topic by providing relevant future research directions. To do so, we conducted a systematic review on the topic of EO published in SCM journals from 1989 to April 2020. We summarize 14 relevant articles on EO in SCM and conclude that research joining these fields is surprisingly scant despite the development of both EO and SCM literature over extended periods of time. We find that although existing research recognizes that entrepreneurial behavior is key for a successful supply chain orientation and to develop more efficient and value-creating supply chains, theoretical development and empirical examination in specific supply chains and multiple industries is required. We uncover and propose specific opportunities to advance this research effort.
\end{abstract}

KEYWORDS: Entrepreneurial orientation, Supply chain orientation, Systematic review, Entrepreneurship, Supply chain management

JEL CLASSIFICATION: L25, L26, M11

Reference: Cortes, A. F., Lee, Y., Cortes, J. D., \& Liñan, I. (2021). Entrepreneurial orientation in supply chain management: A systematic review. International Journal of Entrepreneurial Knowledge, 9(1), 127-143. doi: 10.37335/ijek.v9i1.127

\section{INTRODUCTION}

Developing an entrepreneurial orientation (EO) is a key effort for companies to exploit the dynamics that permeate their environments (Covin \& Slevin, 1989; Lee et al., 2019). As technologies shift constantly and markets change rapidly and precipitate speedy responses to competition, a firm's ability to take calculated risks, assume proactive action, and pursue innovation are essential strategic efforts to achieve greater performance (Rauch et al., 2009). However, value-creating initiatives, such as the introduction of new products and services, come with uncertain and challenging development, logistics, and distribution difficulties that firms need to manage effectively to see their strategies implemented 


\section{INTERNATIONAL JOURNAL OF ENTREPRENEURIAL KNOWLEDGE}

Issue 1, volume 9, ISSN 2336-2960 (Online)

www.ijek.org

successfully. This issue underscores that successful entrepreneurial endeavors need the support of effective supply chain management (SCM) practices.

This important and symbiotic relationship between EO and SCM seems intuitive. Prominent examples such as Apple and Amazon also indicate that it is highly important for companies to differentiate their offerings while running efficient and effective operations. Furthermore, surveys suggest that most executives consider their company's survival to depend on their capability to innovate by collaborating with supply chain partners (Koetzier \& Alon, 2013). However, from a scholarly perspective, the connection between entrepreneurship and supply chain literature remains in its early theoretical stages, and no research has attempted to synthesize their intersection, making their unquestionable synergy more apparent and in urgent need of a comprehensive review.

Our study aims to fill this important gap in two ways. First, we analyze research linking entrepreneurship and SCM by reviewing studies of EO and supply chain orientation (SCO). On the one hand, EO represents a firm-level, strategic posture in which firms engage in innovative activities, proactively disrupt new markets, and embrace the corresponding risks of pursuing new opportunities (Covin \& Slevin, 1989; Lumpkin \& Dess, 1996; Miller, 1983). The academic and practitioner interest in $\mathrm{EO}$ is certainly influenced by the significant relationship found between EO and firm performance (Covin \& Wales, 2019). Scholars found that entrepreneurial firms tend to outperform competitors that are managed more conservatively (Rauch et al., 2009). On the other hand, SCO refers to the inclination of a firm's top management to recognize the synergetic link between tactical supply chain activities, that enable effective management of the different flows in the firm's supply chain, and its strategic firmlevel consequences (Mentzer et al., 2001). In a company with high SCO, top management will foster trust and commitment with supply chain partners through cooperative norms (Mello \& Stank, 2005). Similar to EO, the application of SCO has been found positively related to firm performance (Min \& Mentzer, 2004). We focus on EO and SCO to provide a comprehensive review and follow concepts that are established in both entrepreneurship and supply chain fields.

Second, we aim to stimulate the theoretical development of thought-provoking relationships as well as provide guidance for future research linking EO and SCO empirically. Although when studied individually, EO and SCO have been positively related to firm performance, when considered together, $\mathrm{EO}$ and SCO could be perceived as incompatible orientations. One of the causes could be the biased perception of academics on each side of the fence (Goodale et al., 2011). On the one hand, academics that study SCM may focus their attention on the benefits of a coordinated and collaborative relationship between agents in the supply chain, but may also be wary of the disruptive effects of entrepreneurial behaviors that require fulfilling costly promises and perhaps jeopardize current working processes and alliances. On the other hand, academics that study entrepreneurship focus their attention on aspects related to innovation and new ventures and may be biased to consider SCM practices as inhibitors to firm agility, efficiency, and exploitation of well-known practices. Yet, the coexistence of EO and SCO can be observed in all kinds of successful companies, and we argue that such successful coexistence warrants further theoretical development and empirical examination.

The structure of this paper is as follows. First, we provide an overview of the conceptualizations and findings of EO and SCO. Second, we review the literature of EO in SCM journals in order to assess the interest and understanding of EO in the SCM field. Then, we provide a detailed overview of conclusions and relationships on this research and advance relevant suggestions for future inquiry. Finally, we close by summarizing the most important elements from our review that require future attention and discussing relevant practical implications. 
INTERNATIONAL JOURNAL OF ENTREPRENEURIAL KNOWLEDGE

Issue 1, volume 9, ISSN 2336-2960 (Online)

www.ijek.org

\section{LITERATURE REVIEW}

\subsection{Entrepreneurial Orientation}

Entrepreneurial orientation (EO) refers to strategic postures of firms that are entrepreneurial (Covin \& Slevin, 1989; Miller, 1983). Miller (1983) explained that an entrepreneurial firm "engages in productmarket innovation, undertakes somewhat risky ventures, and is first to come up with 'proactive' innovations, beating competitors to the punch" (p. 771). Specifically, EO contains three core components: innovativeness, proactiveness, and risk-taking (Covin \& Slevin, 1989; Miller, 1983). Innovativeness refers to participating in creative activities and experimenting through launching new products or services, and leading new processes of research and development (R\&D) through technological leadership; proactiveness is defined as forward-looking and opportunity-seeking behaviors in expectation of future demand; risk-taking means bold movement in venturing undiscovered area and heavy investments to ventures under uncertainty (Lumpkin \& Dess, 1996; Miller \& Friesen, 1978; Venkatraman, 1989).

From the seminal work on EO (Covin \& Slevin, 1989), scholars regarded EO as a unidimensional construct that three prominent dimensions of $\mathrm{EO}$ to be aggregated together to form an overall degree of EO. From this view, different components of EO should covary. Scholars also suggested that each EO component could vary (e.g., Gupta, 2015; Kreiser et al., 2002; Lumpkin \& Dess, 1996, 2001), referring that $\mathrm{EO}$ is a multidimensional construct manifesting diverse degrees of components to form an overall level of EO. Specifically, this perspective contends that components of EO could have different strengths and directions toward diverse outcomes. EO scholars explained that "intellectual advancement pertaining to EO will likely occur as a function of how clearly and completely scholars can delineate the pros and cons of alternative conceptualizations of the EO construct and the conditions under which the alternative conceptualizations may be appropriate" (Covin et al., 2006, p. $80)$.

Recently, entrepreneurship scholars have reconceptualized EO into two lower-order dimensions: managerial attitude towards risk (i.e., risk-taking) and entrepreneurial behavior (i.e., the exhibition of innovativeness and proactiveness) (Anderson et al., 2015). Managerial attitude towards risk refers to the managerial inclination toward favoring high risk-taking actions (Miller, 1983). Moreover, entrepreneurial behavior is pursuing new products, services, and processes (i.e., innovativeness) with the intention of commercialization ahead of the competition (i.e., proactiveness) (Anderson et al., 2015). They combined innovativeness and proactiveness into one dimension, entrepreneurial behavior, for several reasons. First, they argued that there is low face validity in the attitudinal assumptions in both innovativeness and proactiveness. Second, innovativeness is not a sufficient condition for entrepreneurship, but a necessary condition. Also, innovativeness is not fully independent from proactiveness in entrepreneurship phenomenon (Rosenbusch et al., 2011). Therefore, Anderson et al. (2015) justified that "innovativeness and proactiveness are functionally equivalent reflections of the underlying entrepreneurial behaviors dimension" (p. 1583). Scholars could benefit from this newly developed perspective on EO and take the view that risk-taking attitude and entrepreneurial behavior are collectively necessary components to establish the higher-order EO. Moreover, scholars could extend a multidimensional conceptualization of EO and assert that components of EO would vary from each other. One possible issue of reflective measurement is that it assumes sub-components are equally valid, completely covary, and eventually share similar causes and outcomes (Bollen, 1989). This assumption has been opposed by other EO researchers that EO components would have different relationships among and between them toward specific outcomes (e.g., George \& Marino, 2011). Building on these different conceptualizations and operationalizations of $\mathrm{EO}$, scholars need to take an appropriate theoretical lens and contextual justifications to advance the EO literature. 
INTERNATIONAL JOURNAL OF ENTREPRENEURIAL KNOWLEDGE

Issue 1, volume 9, ISSN 2336-2960 (Online)

www.ijek.org

\subsection{Supply Chain Orientation}

Strict definitions of SCM have been subject to inconclusive debate. A well-known framework by Mentzer et al. (2001) describes it from three different perspectives: 1) management philosophy, 2) management activity, and 3) management process. First, the management philosophy perspective of SCM treats the supply chain as a single entity that includes a set of entities (i.e., customers and suppliers), whose efforts are aimed at the efficient flow of goods from the main first source to their ultimate end customer. Under this paradigm, entities participating in the supply chain are tightly integrated and make supply chain-wide strategic initiatives (e.g., innovation and resource sharing) to increase the value-added to the end customer. Second, supply chain as a management activity interprets the supply chain not as a single entity but as a set of multi-firm strategic management principles that seek a coordinated effort to satisfy the needs of the end customer. This perspective places high importance on information sharing and a desire to share challenges and compensations across the partners of the supply chain. Third, SCM as a management process is defined as the managerial actions that align relationships and manage the flow of information and materials across a set of firms to add value and attain the expected level of customer service. A commonality, across the three lenses by which SCM is seen, is the need for entities to collaborate with one another via primarily sharing information and increasing trust, toward activities that will add value as seen by the end customer.

Conversely to the definition of SCM, supply chain orientation (SCO) is defined for the focal firm (i.e., a single entity in the supply chain). SCO represents a firm's strategic orientation toward recognizing the importance of SCM (Mentzer et al., 2001). Thus, supply chain oriented firms will have a top management team that understands the value of managing the upstream and downstream flow of goods, services, information, among others, from a source to a customer, and the potential competitive advantage that can be created by doing so efficiently (Mentzer et al., 2001).

Specifically, SCO is operationalized with five values: 1) trust, 2) commitment, 3) cooperative norms, 4) organizational compatibility, and 5) top management support (Kirchoff et al., 2016). Trust is a relational facilitator, that allows firms to achieve greater benefits from knowledge transfer and joint learning. Trust motivates firms to share risks related to exploring and exploiting new initiatives (Nahapiet \& Ghoshal, 1998). Commitment happens when "an exchange partner believing that an ongoing relationship with another is so important as to warrant maximum efforts at maintaining it; that is, the committed party believes the relationship endures indefinitely" (Morgan \& Hunt, 1994, p. 23). Morgan and Hunt (1994) posited that "when both commitment and trust - not just one or the other - are present, they produce outcomes that promote efficiency, productivity and effectiveness" (p. 22). Trust and commitment then could allow companies to collaborate and focus on the long term, increasing risk pooling and accepting ventures that can bring them further differentiation from competitors. Cooperative norms can allow supply chain partners to seek mutual efforts to accomplish joint goals (Siguaw et al., 1998). Cooperative norms align the firm's goals and reduce instances of opportunism. Cooperating firms work together and have similar incentives to not default. Organizational compatibility decreases possible friction between firms and enhances the rates of success of the collaboration by creating a common identity and motivation to pursue congruent goals (Patel et al., 2013). Finally, top management support provides the focus and resources to sustain robust relationships with supply chain members (Mentzer et al., 2001). Top management support decreases the transaction costs between supply chain partners, as lower monitoring costs are incurred. The more a company's culture embraces SCO, the more the firm will attract other companies with a similar orientation. Those companies will be more willing to share risks, rewards, and information, combine efforts, seek partners with well-matched goals and have the backing of top management with the consequent resources (Mello \& Stank, 2005). 


\section{INTERNATIONAL JOURNAL OF ENTREPRENEURIAL KNOWLEDGE}

Issue 1, volume 9, ISSN 2336-2960 (Online)

www.ijek.org

SCO has been shown to have positive performance benefits, attained by better aligning resources throughout the supply chain with the kinds of goods that flow therein. This strategic alignment requires supply chain-wide efforts to develop mechanics for information exchange and trust across entities in the supply chain (Esper et al., 2010). However, even though a positive relationship between SCO and performance has been shown, primarily due to effective knowledge transfer (Whitehead et al., 2019), the body of literature has provided mixed findings when the relationship between SCO and environmental and social sustainability is studied (Hsu et al., 2016; Jadhav et al., 2019).

Similarly, the relationship between resource alignment and higher levels of performance does not need to be reified. It has been long shown that by aligning its efforts strategically with the goods that flow through its processes, firms can more effectively add value toward meeting end customer needs (Skinner, 1974, 1996). However, this still constitutes a silo mentality (absent of SCO), and further investigation of the implications of a firm's SCO (or absence thereof) is thus valuable to shed light as to its entanglement with other firms upstream or downstream in the supply chain.

The mechanisms and, more importantly, the extent to which SCO can turn into a supply chain-wide inhibitor of innovation or entrepreneurial activities (given a need to withhold or limit sharing of intellectual capital, information, or joint decision-making capabilities) need to be further outlined. Lower levels of information sharing might, on the one hand, decrease effective SCM via a reduced SCO but, on the other hand, may increase levels of entrepreneurial activities throughout the supply chain. Under this lens, a barrier to resource and information sharing across the members of the supply chain might still bring benefits in the form of increased agility and long-term innovation in the supply chain.

\section{SYSTEMATIC REVIEW}

SCM literature has not been indifferent to the entrepreneurship concept considering that the intersection between SCM and entrepreneurship can lead to value creation and sustainable competitive advantage (Kickul et al., 2011). To understand the significance of entrepreneurship for SCM scholars, we performed a systematic literature review following the six main steps delineated by Durach et al. (2017): 1) clarifying the research question, 2) specifying the characteristics of focal studies, 3) gathering the potentially related literature, 4) choosing the studies that clearly fit criteria, 5) integrating the literature, and 6) reporting or describing the findings. First, our question was defined as follows: how has the EO concept been studied and/or explored in the SCM literature? Second, we considered peerreviewed articles published in seven top-tier supply chain and operations management; Decision Sciences, International Journal of Logistics Management, International Journal of Physical Distribution and Logistics Management, Journal of Business Logistics, Journal of Operations Management, Journal of Supply Chain Management, and Transportation Journal. These seven journals have been used by scholars conducting literature reviews in the SCM field (Daugherty et al., 2017; Esper \& Peinkofer, 2017). Third, we conducted a comprehensive search in four different databases: ABI/Proquest, Web of Science, SCOPUS, and EBSCO, looking for "entrepren*" in the title, abstract, and keywords. Using "entrepren*", we were making sure that we would capture all the possible words with the root "entrepren" such as entrepreneurship or entrepreneurial. The first year considered in our search was 1989 to match the publication of the seminal work of Covin and Slevin (1989). This time frame provides us with a sample of more than 30 years (from 1989 to April 2020). A total of 150 articles were found after merging all the results from the databases. In the fourth step, we proceeded to select pertinent studies by reviewing each article individually and evaluating the study in light of our defined selection criteria and research question. We also excluded editorials articles and articles whose focus was not primarily related to EO. This final step led to a final sample of 14 articles included in our review. 


\section{INTERNATIONAL JOURNAL OF ENTREPRENEURIAL KNOWLEDGE}

Issue 1, volume 9, ISSN 2336-2960 (Online)

www.ijek.org

\section{FINDINGS}

We provide a categorization of the use of the EO construct in SCM by analyzing dimensions, scales, antecedents, and findings of those articles in the context of SCM. By reviewing these studies systematically, we identified conceptualizations, variables, and other key characteristics of the literature (Wales et al., 2013). We present our categorization in Appendix and present relevant findings and insights below.

As shown in Appendix, the EO construct and its dimensions have been used in several ways in the SCM literature. Although the EO construct has mostly been used as a unidimensional antecedent (eight times), some works have split the EO dimensions to explore its relationships. For example, Das and Joshi (2007) and Joshi et al. (2015) investigated the interrelation of the EO construct to peer into the black box of entrepreneurship. The authors claim it is the first article to empirically show a curvilinear relationship between proactiveness and innovation. Other works recovered how Miller (1983) used EO dimensions as part of cluster analysis (Ashenbaum et al., 2012; Jambulingam et al., 2005). The use of cluster criteria follows the concept of gestalt (Venkatraman, 1989) and provides the ability to measure fit, or how a determined configuration of multiple dimensions correlates with performance. Related to efficiency, effectiveness, and differentiation, Tuan (2017) found a positive relation between EO and logistics performance. Using a sample of Vietnamese chemical companies, Tuan (2017) explored how customer value co-creation can be achieved through excelling in logistics services and reaching customer organization identification. EO was found to be an important antecedent for logistics performance and an initiator for buyer-supplier successful relationships.

It is worth considering the side effects that an EO may have on relationships between suppliers and buyers. From the buyer's perspective, Tokman et al. (2013) found a significant relationship between increasing levels of EO and decreasing levels of buyer's supplier portfolio flexibility. Surveying over 700 small and medium companies from Finland, Norway, and Sweden, they explored the relationship between supply chain flexibility and satisfaction with their supply chain portfolio. Their findings highlight the possible effect of $\mathrm{EO}$ on limiting the attention of cooperating firms to a few contacts. From the supplier side, Kim et al. (2015) found evidence supporting the claim that suppliers that are relatively more innovative than their peers will tend to focus more on their operations and be less interested in creating new knowledge with their customers. In this case, using a sample of medium-size Korean companies, Kim et al. (2015) found that supplier's entrepreneurship levels negatively moderated the influence of buyer-supplier knowledge transfer on the supplier's operational performance.

With increasing pressure from stakeholders to pursue sustainable practices and evaluate environmental considerations in a supply chain, the role of entrepreneurship in this effort has received some attention (Paulraj, 2011). Pursuing sustainable practices in a supply chain requires important efforts such as developing key relationships, accessing important resources, and going beyond regular institutional norms, thus demanding firms to pioneer novel and risky initiatives (Dyer \& Singh, 1998). A firm that proactively seeks these opportunities and assumes the risks to pursue them can be more likely, for example, to accomplish successful pollution prevention programs or product stewardship initiatives (Paulraj, 2011). On the one hand, the role of entrepreneurship in these environmental endeavors seems particularly relevant given the resource and leadership challenges involved in coordinating all players in a supply chain to adopt sustainable practices. On the other hand, a promising direction on this front would be to explore how firms with low levels of EO tend to adopt sustainable practices. It is likely that insights from institutional theory and competitive dynamics (see Chen \& Miller, 2012; Hwang \& Colyvas, 2020) shed light on how firms ultimately contribute to a sustainable supply chain for reasons other than an entrepreneurial effort to effect change. Furthermore, it would be insightful to explore such phenomena across industries. 


\section{INTERNATIONAL JOURNAL OF ENTREPRENEURIAL KNOWLEDGE}

Issue 1, volume 9, ISSN 2336-2960 (Online)

www.ijek.org

Should entrepreneurial efforts from one firm influence the behavior of other firms in a supply chain, an effective research program exploring the interface between entrepreneurship and SCM needs to advance theorizing on dyadic relationships ( $\mathrm{Li}$ et al., 2011). In this sense, two firms in a supply chain can take advantage of their cooperation to gain strategic knowledge helpful to their activities, but such a relationship can become more valuable when those firms have an EO. More specifically, a distributor with a high EO can provide more valuable information and market knowledge to manufacturers because such propensity toward entrepreneurship entails that the distributor is more responsive to market trends, more likely to cooperate with manufacturers in multiple areas, and more likely to see the benefits of a supply chain collaboration (Li et al., 2011). These findings suggest that firms can see the search of entrepreneurial supply chain partners as a key strategic effort which certainly warrants more investigation from scholars in order to uncover, among other possibilities, how these relationships are established, how they evolve, and the implications they have for other firm-level outcomes.

Finally, note that we could not find published articles of EO in SCM journals in the year 2018, 2019, and 2020. This indicates that the trend of applying firm-level entrepreneurship concepts in the SCM research may be decreasing. Although scholars emphasized cross-disciplinary studies in the SCM literature (Kickul et al., 2011), our result implies that EO has been neglected in the SCM literature recently. The topic of EO is making progress in the entrepreneurship literature (Covin \& Wales, 2019); for instance, scholars recently introduced concepts like strategic entrepreneurial behaviors (Anderson et al., 2019). Beyond the entrepreneurship literature, scholars recently applied EO in other disciplines and topics such as marketing (Arunachalam et al., 2018) and corporate social responsibility (Zhuang et al., 2020). Acknowledging the lack of recent EO studies in the SCM literature, we suggest future research opportunities to apply the former in the latter, below.

\section{DISCUSSION AND FUTURE DIRECTIONS}

We reviewed how the concept of EO has been studied in the SCM literature. Our review suggests that EO can lead to positive SCO outcomes and that there are several opportunities to continue developing the relationships between EO and relevant supply chain concepts. Overall, a key highlight of our work is the suggestion to 'bring down the fence' and become open to the possibilities that offer combining insights from two disciplines that have mostly developed in silos: entrepreneurship and SCM. We elaborate on some relevant suggestions and preliminary theoretical development below.

\subsection{Relying on Established Frameworks}

Transaction cost economics (TCE) has been identified as one of the most applied theories in the SCM literature (Defee et al., 2010; Swanson et al., 2017). For example, TCE has been widely used in SCM research for evaluating vertical integration (Ellram, 1991) or identifying the relevant factors in a contractual relationship (Van Hoek, 2000). TCE is based on bounded rationality, uncertainty, and asset specificity (Williamson, 1981). The theory provides a framework to evaluate the cost of relationships among companies in a supply chain. Bounded rationality acknowledges the limitation for decision makers to acquire, comprehend, and apply information (Williamson, 1981). Uncertainty considers environmental factors, demand uncertainty, and the ambiguity of other stakeholders' actions. Asset specificity relates to assets or resources tied up in the relationship. Those assets are not easily redeployable. Usually, those resources are not available to use for other clients/ suppliers or are less valuable to use with different clients/ suppliers. The main tenant of TCE is that firms will "organize transactions so as to economize on bounded rationality while simultaneously safeguarding them against the hazards of opportunism" (Williamson, 1996, p. 254).

As seen in the literature review of EO in SCM journals, there is still no clarity of the effect of EO and SCO on efficiency, effectiveness, and differentiation. However, TCE can help clarify that relationship. 


\section{INTERNATIONAL JOURNAL OF ENTREPRENEURIAL KNOWLEDGE}

Issue 1, volume 9, ISSN 2336-2960 (Online)

www.ijek.org

As EO brings innovation, proactiveness, and risk-taking to the firm, a more dynamic relationship is needed between supply chain partners. Supply chain partners then will evaluate the transaction costs of maintaining that relationship, such as the investment costs required to maintain the relationship, the monitoring costs, and the possible risks of opportunistic actions of the other parties. If supply chain partners feel the relationship costs are too high, then they will limit their exposure and collaboration with other partners. Partners will need further assurance of the relationship to continue to be engaged in a fulfilling relationship. SCO can facilitate reducing the transaction cost as it requires top management to acknowledge the importance of collaboration for long-term benefits (Mello \& Stank, 2005).

\subsection{Links to Specific Facets of SCM}

Much empirical evidence links EO to overall firm performance (Fadda, 2018; Rauch et al., 2009), but there is potential to explore the influence of $\mathrm{EO}$ on more specific aspects of SCM, namely efficiency, effectiveness, and differentiation. A firm that acts entrepreneurially will seek new ways of doing business that will cause disruption in the rules of competition of the industry (Kuratko \& Audretsch, 2009). Consequently, the generation and implementation of new internal processes, the introduction of new products and the expansion into new markets, or the radical development of new product-markets are key efforts of entrepreneurial activity (Covin \& Slevin, 1989; Hughes et al., 2021) that can enhance efficiency, effectiveness, and differentiation when resources are managed properly (Ireland et al., 2009).

For example, entrepreneurial firms not only enhance firm differentiation with new products and services but also strive to eliminate waste by divesting older products (Covin \& Miles, 1999). A selective offering of products and services avoids unnecessary use of resources such as excess inventory or unnecessary costs such as obsolescence. The fact that companies are diligent in balancing and updating their product and service portfolios is likely to increase the efficiency of their results. Furthermore, firms that alter their internal processes and structures in order to improve their competitive standing can facilitate innovation not only in 'hard sides' (i.e., products) but additionally in 'soft sides' (i.e., logistics service delivery) (Cui et al., 2012). Other internal aspects can be found improving product design, manufacturing, or delivery of products and services. Results from these efforts can be seen in the product cycle, reduction of costs, increased reliability, and speed to market, hence, promoting efficiency, effectiveness, and differentiation.

Firms with high EO are also likely to redefine relationships with their markets by making important changes in competitive behavior (Covin \& Miles, 1999) or by redefining the boundaries of existing industries (Kuratko \& Audretsch, 2009). Faber Castell, for example, faced a changing environment in which their customers were switching to using digital tools. Additionally, competitors were able to produce lower-cost products in developing countries. Faber Castell decided to reinvent its strategy with two key initiatives. First, investing upstream, Faber Castell started purchasing forests located in Brazil to secure raw material availability (Raffaelli, 2017). On the downstream side, Faber Castell rebranded the company as a 'companion of life'. This way, they changed their strategy and repositioned their offering to match the needs of different customer segments. Additionally, they transformed their product range into a variety of differentiated quality classic tools that will serve the life cycle of the customer (Raffaelli, 2017). In short, Faber Castell increased their effectiveness by securing raw material for its products and achieved differentiation by its new branding and product segmentation. The case of Nintendo Wii serves as another example. While Sony and Microsoft were competing with superior graphics quality and more adult content video games, Nintendo saw an opportunity to create an uncontested market. Nintendo launched a family-friendly alternative that was perceived by the customer as something completely new and widely accepted by the market. Neither Microsoft nor Sony was able to capture this part of the market as effectively, since they were perceived to be video games for more avid gamers. Wii capitalized on this niche, beating the incumbents and outselling their 


\section{INTERNATIONAL JOURNAL OF ENTREPRENEURIAL KNOWLEDGE}

Issue 1, volume 9, ISSN 2336-2960 (Online)

www.ijek.org

competitors (Farhoomand et al., 2009). Overall, these examples serve as anecdotal evidence of how a strong EO can promote a successful SCO.

\subsection{Synergies between EO and SCO}

Pioneering firms realize that competition may transcend the actions of similar companies and rather acknowledge entire supply chains (Christopher, 2016). The complexity of value chains, products, services, and consumer demands makes it almost impossible for a firm to provide all needed parts of the puzzle by itself. Moreover, the competitive battle entails not only physical resources but also knowledge (Vargo \& Lusch, 2004). According to Vargo and Lusch (2004), knowledge is at the core of a firm's competitive advantage. Based on the proposal of value co-creation, a sustainable advantage is rooted in human skills, logistics, knowledge bases, or other key capabilities and resources that competitors cannot easily acquire and represent value for the customer (Vargo \& Lusch, 2004).

EO researchers have shown great interest in knowledge creation and appropriation processes such as acquisitive learning and experimental learning (Kreiser, 2011). The key tasks for entrepreneurial firms are maximizing the benefits attained from their EO and developing their knowledge boundaries (Hughes et al., 2007). Using the opportunity-value-motivation-ability framework (Nahapiet \& Ghoshal, 1998), Kreiser (2011) proposed that EO enhances the organizational capability of learning orientation and promotes the application of learning to related value activities. Acquisitive learning is fostered by network range and experimental learning is promoted by network closure (Kreiser, 2011). Network closure depends on the "group norms, shared goals, and similar behaviors that turn a network of firms with strong ties to one another into a collective entity" (Kreiser, 2011, p. 1043). Since "a company possesses a supply chain orientation (SCO) if its management can see the implications of managing the upstream and downstream flows of products, services, finances, and information across their suppliers and their customers" (Mentzer et al., 2001, p. 11), the social aspect of SCO should boost the effect of EO by the values that SCO represents. Knowledge gain and application, when considering EO and SCO together, should then be strengthened and result in higher efficiency, effectiveness, and differentiation.

\subsection{Incorporating Firm Size}

In order to overcome diverse obstacles, small firms and new ventures need to become entrepreneurial. On the one hand, affected by the liability of newness (Stinchcombe, 1965), new firms need to be entrepreneurial to overcome the relative lack of legitimacy, reliability, and accountability they possess compared to larger competitors (Farja et al., 2016; Golicic \& Sebastiao, 2011). On the other hand, the assets of newness (Nagy \& Lohrke, 2010) aid new and small firms to compensate for their limitations with congruence and flexibility. This way affects congruence (i.e., benevolent treatment from clients to the new supplier), which allows small firms to collaborate with customers and learn from mistakes. Additionally, flexibility allows small firms to absorb and utilize knowledge from other partners and apply it to create value. Although there is research that finds conflict between small and medium firms and SCM practices (Arend \& Wisner, 2005), success for small firms seems to depend in great part on fostering a SCO with their valuable partners in the chain.

Similar to small firms, EO and SCO may also be relevant for larger firms. The hypercompetitive industry environment in which large firms currently operate calls for constant renovation of capabilities to survive (Eisenhardt \& Martin, 2000). Seeking new risky domains and proactively pursuing new strategies are key entrepreneurial efforts that can promote competitive advantages, but large firms may not be likely to succeed in these efforts without recognizing the strategic importance of SCM when promoting innovation and risk-taking. Furthermore, SCO can play a larger role than only enhancing efficiency and cost reductions in a firm and rather be a catalyst for entrepreneurial efforts. SCO 


\section{INTERNATIONAL JOURNAL OF ENTREPRENEURIAL KNOWLEDGE}

Issue 1, volume 9, ISSN 2336-2960 (Online)

www.ijek.org

considers a systems approach in which agents are interrelated and benefit from cooperation by providing valuable resources to each other under the motivation of meeting congruent goals (Min et al., 2007), which should allow large firms to obtain more benefits by viewing their SCM efforts more strategically.

\subsection{Implications for Practice}

Widening our understanding of the links between EO and SCO can elucidate which types of partnerships (i.e., types of firms that should be entities in the same supply chain) are more likely to lead to increased performance levels. For example, Davis-Sramek et al. (2019) discuss that SCO can lead to better levels of supplier responsiveness. However, SCO alone does not account for risk-taking profiles (e.g., from a strategic, tactical, or final perspective), new market exploration/exploitation capability, and other qualities, that may not be captured from the perspective of SCO, but may be visible from their EO (Lee \& Kreiser, 2018). Similarly, a firm's supply chain agility (i.e., ability to quickly react to changes in the marketplace) can be influenced by its level of SCO and that of its supply chain partners (Gligor et al., 2019). Thus, further knowledge of the interconnectedness of levels of EO and SCO has the potential to circumvent barriers in proper matches of either EO or SCO by establishing better EOSCO links among firms. This alternative paradigm can expand the potential for seemingly incompatible entities to participate and be successful in the same supply chain.

\section{CONCLUSION}

It has become apparent that successful companies manage to introduce new initiatives to the market and build a strong EO while also maintaining efficiency and productivity in their operations, suggesting the importance of reconciling entrepreneurial behaviors and SCM practices. However, despite these intuitive synergies between EO and SCM, scant studies have attempted to synthesize existing research on how EO has been studied in SCM and provided relevant research directions for future scholars to explore. Our systematic literature review addresses this need by synthesizing the most relevant findings from this important topic and providing key areas for future inquiry. We hope our study can encourage further investigation on the relationship between entrepreneurship and SCM.

\section{REFERENCES}

Anderson, B. S., Eshima, Y., \& Hornsby, J. S. (2019). Strategic entrepreneurial behaviors: Construct and scale development. Strategic Entrepreneurship Journal, 13(2), 199-220.

Anderson, B. S., Kreiser, P. M., Kuratko, D. F., Hornsby, J. S., \& Eshima, Y. (2015). Reconceptualizing entrepreneurial orientation. Strategic Management Journal, 36(10), 1579-1596.

Arend, R. J., \& Wisner, J. D. (2005). Small business and supply chain management: is there a fit? Journal of Business Venturing, 20(3), 403-436.

Arunachalam, S., Ramaswami, S. N., Herrmann, P., \& Walker, D. (2018). Innovation pathway to profitability: The role of entrepreneurial orientation and marketing capabilities. Journal of the Academy of Marketing Science, 46(4), 744-766.

Ashenbaum, B., Salzarulo, P. A., \& Newman, W. R. (2012). Organizational structure, entrepreneurial orientation and trait preference in transportation brokerage firms. Journal of Supply Chain Management, 48(1), 3-23.

Bollen, K. A. (1989). A new incremental fit index for general structural equation models. Sociological Methods and Research, 17(3), 303-316.

Brockman, B. K., \& Morgan, R. M. (2003). The role of existing knowledge in new product innovativeness and performance. Decision Sciences, 34(2), 385-419.

Chen, M. J., \& Miller, D. (2012). Competitive dynamics: Themes, trends, and a prospective research platform. Academy of Management Annals, 6(1), 135-210. 


\section{INTERNATIONAL JOURNAL OF ENTREPRENEURIAL KNOWLEDGE}

Issue 1, volume 9, ISSN 2336-2960 (Online)

www.ijek.org

Christopher, M. (2016). Logistics and Supply Chain Management. Pearson.

Covin, J. G., Green, K. M., \& Slevin, D. P. (2006). Strategic process effects on the entrepreneurial orientation-sales growth rate relationship. Entrepreneurship Theory and Practice, 30(1), 57-81.

Covin, J. G., \& Miles, M. P. (1999). Corporate entrepreneurship and the pursuit of competitive advantage. Entrepreneurship Theory and Practice, 23(3), 47-63.

Covin, J. G., \& Slevin, D. P. (1989). Strategic management of small firms in hostile and benign environments. Strategic Management Journal, 10(1), 75-87.

Covin, J. G., \& Wales, W. J. (2019). Crafting high-impact entrepreneurial orientation research: Some suggested guidelines. Entrepreneurship Theory and Practice, 43(1), 3-18.

Cui, L., Su, S.-I. I., \& Hertz, S. (2012). Logistics innovation in China. Transportation Journal, 51(1), 98117.

Das, S. R., \& Joshi, M. P. (2007). Process innovativeness in technology services organizations: Roles of differentiation strategy, operational autonomy and risk-taking propensity. Journal of Operations Management, 25(3), 643-660.

Daugherty, P., Bolumole, Y., \& Schwieterman, M. (2017). Logistics research: What a long, strange trip it's been. Transportation Journal, 56(3), 213-226.

Davis-Sramek, B., Omar, A., \& Germain, R. (2019). Leveraging supply chain orientation for global supplier responsiveness. International Journal of Logistics Management, 25(4), 371-394.

Defee, C. C., Williams, B., Randall, W. S., \& Thomas, R. (2010). An inventory of theory in logistics and SCM research. International Journal of Logistics Management, 21(3), 404-489.

Durach, C. F., Kembro, J., \& Wieland, A. (2017). A new paradigm for systematic literature reviews in supply chain management. Journal of Supply Chain Management, 53(4), 67-85.

Dyer, J. H., \& Singh, H. (1998). The relational view: Cooperative strategy and sources of interorganizational competitive advantage. Academy of Management Review, 23(4), 660-679.

Eisenhardt, K. M., \& Martin, J. A. (2000). Dynamic capabilities: What are they? Strategic Management Journal, 21(10-11), 1105-1121.

Ellram, L. M. (1991). Supply-chain management: The industrial organization perspective. International Journal of Physical Distribution and Logistics Management, 21(1), 13-22.

Esper, T. L., Defee, C. C., \& Mentzer, J. T. (2010). A framework of supply chain orientation. International Journal of Logistics Management, 21(2), 161-179.

Esper, T. L., \& Peinkofer, S. T. (2017). Consumer-based supply chain management performance research: A structured literature review. Transportation Journal, 56(4), 395-428.

Fadda, N. (2018). The effects of entrepreneurial orientation dimensions on performance in the tourism sector. New England Journal of Entrepreneurship, 21(1), 22-44.

Farhoomand, A., Joshi, H., \& Tsang, S. (2009). Nintendo's Disruptive Strategy: Implications for the Video Game Industry. University of Hong Kong.

Farja, Y., Gimmon, E., \& Greenberg, Z. (2016). The effect of entrepreneurial orientation on SMEs growth and export in Israeli peripheral regions. New England Journal of Entrepreneurship, 19(2), 2541.

George, B. A., \& Marino, L. (2011). The epistemology of entrepreneurial orientation: Conceptual formation, modeling, and operationalization. Entrepreneurship Theory and Practice, 35(5), 989-1024.

Gligor, D., Holcomb, M., Maloni, M. J., \& Davis-Sramek, E. (2019). Achieving financial performance in uncertain times: Leveraging supply chain agility. Transportation Journal, 58(4), 247-279.

Golicic, S. L., \& Sebastiao, H. J. (2011). Supply chain strategy in nascent markets: the role of supply chain development in the commercialization process. Journal of Business Logistics, 32(3), 254-273.

Goodale, J. C., Kuratko, D. F., Hornsby, J. S., \& Covin, J. G. (2011). Operations management and corporate entrepreneurship: The moderating effect of operations control on the antecedents of corporate entrepreneurial activity in relation to innovation performance. Journal of Operations Management, 29(1-2), 116-127.

Gupta, V. K. (2015). Construction of entrepreneurial orientation: Dispute, demand, and dare. New England Journal of Entrepreneurship, 18(1), 87-89. 
INTERNATIONAL JOURNAL OF ENTREPRENEURIAL KNOWLEDGE

Issue 1, volume 9, ISSN 2336-2960 (Online)

www.ijek.org

Hsu, C.-C., Tan, K.-C., \& Zailani, S. H. M. (2016). Strategic orientations, sustainable supply chain initiatives, and reverse logistics. International Journal of Operations and Production Management, 36(1), 86-110.

Hughes, M., Hughes, P., \& Morgan, R. E. (2007). Exploitative learning and entrepreneurial orientation alignment in emerging young firms: Implications for market and response performance. British Journal of Management, 18(4), 359-375.

Hughes, M., Hughes, P., Morgan, R. E., Hodgkinson, I. R., \& Lee, Y. (2021). Strategic entrepreneurship behaviour and the innovation ambidexterity of young technology-based firms in incubators. International Small Business Journal, 39(3), 202-227.

Hwang, H., \& Colyvas, J. A. (2020). Ontology, levels of society, and degrees of generality: Theorizing actors as abstractions in institutional theory. Academy of Management Review, 45(3), 570-595.

Ireland, R. D., Covin, J. G., \& Kuratko, D. F. (2009). Conceptualizing corporate entrepreneurship strategy. Entrepreneurship Theory and Practice, 33(1), 19-46.

Ireland, R. D., \& Webb, J. W. (2007). A multi-theoretic perspective on trust and power in strategic supply chains. Journal of Operations Management, 25(2), 482-497.

Jadhav, A., Orr, S., \& Malik, M. (2019). The role of supply chain orientation in achieving supply chain sustainability. International Journal of Production Economics, 217, 112-125.

Jambulingam, T., Kathuria, R., \& Doucette, W. R. (2005). Entrepreneurial orientation as a basis for classification within a service industry: The case of retail pharmacy industry. Journal of Operations Management, 23(1), 23-42.

Joshi, M. P., Das, S. R., \& Mouri, N. (2015). Antecedents of innovativeness in technology-based services (TBS): Peering into the black box of entrepreneurial orientation. Decision Sciences, 46(2), 367-402.

Kach, A., Busse, C., Azadegan, A., \& Wagner, S. M. (2016). Maneuvering through hostile environments: How firms leverage product and process innovativeness. Decision Sciences, 47(5), 907-956.

Kickul, J. R., Griffiths, M. D., Jayaram, J., \& Wagner, S. M. (2011). Operations management, entrepreneurship, and value creation: Emerging opportunities in a cross-disciplinary context. Journal of Operations Management, 29(1-2), 78-85.

Kim, H., Hur, D., \& Schoenherr, T. (2015). When buyer-driven knowledge transfer activities really work: A motivation-opportunity-ability perspective. Journal of Supply Chain Management, 51(3), 3360.

Kirchoff, J. F., Tate, W. L., \& Mollenkopf, D. A. (2016). The impact of strategic organizational orientations on green supply chain management and firm performance. International Journal of Physical Distribution and Logistics Management, 46(3), 269-292.

Koetzier, W., \& Alon, A. (2013). Why "Low Risk" Innovation is Costly. Accenture.

Kreiser, P. M. (2011). Entrepreneurial orientation and organizational learning: The impact of network range and network closure. Entrepreneurship Theory and Practice, 35(5), 1025-1050.

Kreiser, P. M., Marino, L. D., \& Weaver, K. M. (2002). Assessing the psychometric properties of the entrepreneurial orientation scale: A multi-country analysis. Entrepreneurship Theory and Practice, 26(4), 71-93.

Kuratko, D. F., \& Audretsch, D. B. (2009). Strategic entrepreneurship: Exploring different perspectives of an emerging concept. Entrepreneurship Theory and Practice, 33(1), 1-17.

Lee, Y., \& Kreiser, P. M. (2018). Entrepreneurial orientation and ambidexterity: Literature review, challenges, and agenda for future research. In D. F. Kuratko \& S. Hoskinson (Eds.), The Challenges of Corporate Entrepreneurship in the Disruptive Age (pp. 37-62). Emerald.

Lee, Y., Zhuang, Y., Joo, M., \& Bae, T. J. (2019). Revisiting Covin and Slevin (1989): Replication and extension of the relationship between entrepreneurial orientation and firm performance. Journal of Business Venturing Insights, 12, e00144. 
INTERNATIONAL JOURNAL OF ENTREPRENEURIAL KNOWLEDGE

Issue 1, volume 9, ISSN 2336-2960 (Online)

www.ijek.org

Li, Y., Liu, Y., \& Liu, H. (2011). Co-opetition, distributor's entrepreneurial orientation and manufacturer's knowledge acquisition: Evidence from China. Journal of Operations Management, 29(1-2), 128-142.

Lumpkin, G. T., \& Dess, G. G. (1996). Clarifying the entrepreneurial orientation construct and linking it to performance. Academy of Management Review, 21(1), 135-172.

Lumpkin, G. T., \& Dess, G. G. (2001). Linking two dimensions of entrepreneurial orientation to firm performance: The moderating role of environment and industry life cycle. Journal of Business Venturing, 16(5), 429-451.

Mello, J. E., \& Stank, T. P. (2005). Linking firm culture and orientation to supply chain success. International Journal of Physical Distribution and Logistics Management, 35(8), 542-554.

Mentzer, J. T., DeWitt, W., Keebler, J. S., Min, S., Nix, N. W., Smith, C. D., \& Zacharia, Z. G. (2001). Defining supply chain management. Journal of Business Logistics, 22(2), 1-25.

Miller, D. (1983). The correlates of entrepreneurship in three types of firms. Management Science, 29(7), 770-791.

Miller, D., \& Friesen, P. H. (1978). Archetypes of strategy formulation. Management Science, 24(9), 921933.

Min, S., \& Mentzer, J. T. (2004). Developing and measuring supply chain management concepts. Journal of Business Logistics, 25(1), 63-99.

Min, S., Mentzer, J. T., \& Ladd, R. T. (2007). A market orientation in supply chain management. Journal of the Academy of Marketing Science, 35(4), 507-522.

Morgan, R. M., \& Hunt, S. D. (1994). The commitment-trust theory of relationship marketing. Journal of Marketing, 58(3), 20-38.

Nagy, B., \& Lohrke, F. (2010). Only the good die young? A review of liability of newness and related new venture mortality research. In H. Landström \& F. T. Lohrke (Eds.), Historical Foundations in Entrepreneurship Research (pp. 185-204). Edward Elgar.

Nahapiet, J., \& Ghoshal, S. (1998). Social capital, intellectual capital, and the organizational advantage. Academy of Management Review, 23(2), 242-266.

Patel, P. C., Azadegan, A., \& Ellram, L. M. (2013). The effects of strategic and structural supply chain orientation on operational and customer-focused performance. Decision Sciences, 44(4), 713-753.

Paulraj, A. (2011). Understanding the relationships between internal resources and capabilities, sustainable supply management and organizational sustainability. Journal of Supply Chain Management, 47(1), 19-37.

Raffaelli, R. L. (2017). Faber-Castell doubles down on the pencil. Harvard Business School Working Knowledge. Available at: http://hbswk.hbs.edu/item/faber-castell-doubles-down-on-the-pencil (accessed March 29, 2020)

Rauch, A., Wiklund, J., Lumpkin, G. T., \& Frese, M. (2009). Entrepreneurial orientation and business performance: An assessment of past research and suggestions for the future. Entrepreneurship Theory and Practice, 33(3), 761-787.

Rosenbusch, N., Brinckmann, J., \& Bausch, A. (2011). Is innovation always beneficial? A meta-analysis of the relationship between innovation and performance in SMEs. Journal of Business Venturing, 26(4), 441-457.

Siguaw, J. A., Simpson, P. M., \& Baker, T. L. (1998). Effects of supplier market orientation on distributor market orientation and the channel relationship: The distributor perspective. Journal of Marketing, 62(3), 99-111.

Skinner, W. (1974). The focused factory. Harvard Business Review, 52(3) 113-121.

Skinner, W. (1996). Manufacturing strategy on the "S" curve. Production and Operations Management, 5(1), 3-14.

Stinchcombe, A. L. (1965). Social structure and organizations. In J. G. March (Ed.), Handbook of Organizations (pp. 142-193). Rand McNally. 
INTERNATIONAL JOURNAL OF ENTREPRENEURIAL KNOWLEDGE

Issue 1, volume 9, ISSN 2336-2960 (Online)

www.ijek.org

Swanson, D., Goel, L., Francisco, K., \& Stock, J. (2017). Applying theories from other disciplines to logistics and supply chain management: A systematic literature review. Transportation Journal, 56(3), 299-356.

Tokman, M., Richey, R. G., Morgan, T. R., Marino, L., \& Dickson, P. H. (2013). SME supply chain portfolios: Firm satisfaction and organization resources. International Journal of Logistics Management, 24(2), 271-300.

Tuan, L. T. (2017). Under entrepreneurial orientation, how does logistics performance activate customer value co-creation behavior? International Journal of Logistics Management, 28(2), 600-633.

Van Hoek, R. I. (2000). Role of third party logistic services in customization through postponement. International Journal of Service Industry Management, 36(4), 14-26.

Vargo, S. L., \& Lusch, R. F. (2004). The four service marketing myths: Remnants of a goods-based, manufacturing model. Journal of Service Research, 6(4), 324-335.

Venkatraman, N. (1989). The concept of fit in strategy research: Toward verbal and statistical correspondence. Academy of Management Review, 14(3), 423-444.

Wales, W. J., Gupta, V. K., \& Mousa, F.-T. (2013). Empirical research on entrepreneurial orientation: An assessment and suggestions for future research. International Small Business Journal, 31(4), $357-$ 383.

Whitehead, K., Zacharia, Z., \& Prater, E. (2019). Investigating the role of knowledge transfer in supply chain collaboration. International Journal of Logistics Management, 30(1), 284-302.

Williamson, O. E. (1981). The economics of organization: The transaction cost approach. American Journal of Sociology, 87(3), 548-577.

Williamson, O. E. (1996). The Mechanisms of Governance. Oxford University Press.

Zhuang, Y., Lee, Y., Chang, X., \& Kim, R. B. (2020). Entrepreneurial orientation and corporate social responsibility performance: An empirical study of state-controlled and privately controlled firms in China. Corporate Social Responsibility and Environmental Management, 27(1), 383-392.

\section{BRIEF DESCRIPTION OF AUTHORS:}

\section{Andres Felipe Cortes}

ORCID ID: 0000-0001-6865-3516

Assistant Professor of Management, Welch College of Business and Technology, Sacred Heart University, Fairfield, Connecticut, USA 06825. E-mail: cortesortiza@sacredheart.edu

\section{Younggeun Lee}

ORCID ID: 0000-0002-4723-2728

Assistant Professor of Entrepreneurship, College of Business and Economics, California State University, Los Angeles, California, USA 90032. E-mail: ylee16@calstatela.edu

\section{Juan David Cortes}

ORCID ID: 0000-0002-7385-9639

Assistant Professor of Operations Management, School of Business, Providence College, Providence, Rhode Island, USA 02918. E-mail: david.cortes@providence.edu

\section{Isidro Liñan}

ORCID ID: 0000-0002-3306-5658

Ph.D. Candidate of Supply Chain Management, Ivy College of Business, Iowa State University, Ames, Iowa, USA 50011. E-mail: isidro@iastate.edu 
INTERNATIONAL JOURNAL OF ENTREPRENEURIAL KNOWLEDGE

Issue 1, volume 9, ISSN 2336-2960 (Online)

www.ijek.org

Appendix. Summary of EO Studies in the SCM Literature

\begin{tabular}{|c|c|c|c|c|c|}
\hline Year & Authors & $\begin{array}{c}\text { EO } \\
\text { Dimensions }\end{array}$ & $\begin{array}{c}\text { EO } \\
\text { Used As }\end{array}$ & $\begin{array}{c}\text { Dependent } \\
\text { Variable } \\
\end{array}$ & Findings \\
\hline 2017 & Tuan & $\begin{array}{l}\text { Innovativeness } \\
\text { Proactiveness } \\
\text { Risk-taking }\end{array}$ & Antecedent & $\begin{array}{l}\text { Logistics } \\
\text { performance }\end{array}$ & $\begin{array}{l}\text { Supplier's EO is positively } \\
\text { associated with logistics } \\
\text { performance. }\end{array}$ \\
\hline 2016 & Hsu et al. & $\begin{array}{l}\text { Innovativeness } \\
\text { Proactiveness } \\
\text { Risk-taking }\end{array}$ & Antecedent & SCM practices & $\begin{array}{l}\text { Innovativeness and } \\
\text { proactiveness are antecedents } \\
\text { of SCM practices. Product } \\
\text { advantage is not related to } \\
\text { SCM practices. }\end{array}$ \\
\hline 2016 & Kach et al. & $\begin{array}{l}\text { Product } \\
\text { innovativeness } \\
\text { Process } \\
\text { Innovativeness }\end{array}$ & Mediator & $\begin{array}{c}\text { Firm } \\
\text { performance }\end{array}$ & $\begin{array}{l}\text { Market decline and resource } \\
\text { scarcity are negatively related } \\
\text { to product innovativeness. } \\
\text { Competition is positively } \\
\text { associated with product } \\
\text { innovation. Product } \\
\text { innovation suppresses } \\
\text { restrictiveness and } \\
\text { competition and increases } \\
\text { resource scarcity effect on } \\
\text { firm performance. } \\
\text { Competition and resource } \\
\text { scarcity are positively } \\
\text { associated with process } \\
\text { innovativeness. Process } \\
\text { innovativeness suppresses } \\
\text { coopetition and resource } \\
\text { scarcity. }\end{array}$ \\
\hline 2015 & Joshi et al. & $\begin{array}{l}\text { Innovativeness } \\
\text { Proactiveness } \\
\text { Risk-taking }\end{array}$ & $\begin{array}{l}\text { Antecedent } \\
\text { and } \\
\text { Outcome }\end{array}$ & Innovativeness & $\begin{array}{l}\text { Excessive levels of } \\
\text { proactiveness are detrimental } \\
\text { to innovativeness. } \\
\text { Proactiveness is curvilinear } \\
\text { positive with innovativeness, } \\
\text { but risk-taking is only } \\
\text { positive, not curvilinear. Risk- } \\
\text { taking is positively associated } \\
\text { with innovation and } \\
\text { organizational structure } \\
\text { formality moderates this } \\
\text { relationship. }\end{array}$ \\
\hline 2015 & Kim et al. & $\begin{array}{l}\text { Innovativeness } \\
\text { Autonomy }\end{array}$ & Moderator & $\begin{array}{l}\text { Operational } \\
\text { performance }\end{array}$ & $\begin{array}{l}\text { The influence of buyer-driven } \\
\text { knowledge transfer on } \\
\text { operational performance of } \\
\text { supplier is negatively } \\
\text { amplified by supplier } \\
\text { innovativeness. }\end{array}$ \\
\hline
\end{tabular}


INTERNATIONAL JOURNAL OF ENTREPRENEURIAL KNOWLEDGE

Issue 1, volume 9, ISSN 2336-2960 (Online)

www.ijek.org

\begin{tabular}{|c|c|c|c|c|c|}
\hline Year & Authors & $\begin{array}{c}\text { EO } \\
\text { Dimensions }\end{array}$ & $\begin{array}{c}\text { EO } \\
\text { Used As }\end{array}$ & $\begin{array}{l}\text { Dependent } \\
\text { Variable }\end{array}$ & Findings \\
\hline 2013 & $\begin{array}{c}\text { Tokman et } \\
\text { al. }\end{array}$ & $\begin{array}{l}\text { Innovativeness } \\
\text { Proactiveness } \\
\text { Risk-taking }\end{array}$ & Moderator & $\begin{array}{l}\text { Supply chain } \\
\text { portfolio } \\
\text { performance }\end{array}$ & $\begin{array}{l}\text { EO negatively moderates the } \\
\text { impact of supply chain } \\
\text { portfolio flexibility on } \\
\text { performance satisfaction. }\end{array}$ \\
\hline 2012 & $\begin{array}{l}\text { Ashenbaum } \\
\text { et al. }\end{array}$ & $\begin{array}{l}\text { Innovativeness } \\
\text { Proactiveness } \\
\text { Risk-taking } \\
\text { Aggressiveness }\end{array}$ & Antecedent & $\begin{array}{c}\text { Firm } \\
\text { performance }\end{array}$ & $\begin{array}{l}\text { Transportation brokerages } \\
\text { view themselves as } \\
\text { entrepreneurial. Captive } \\
\text { brokerages are less } \\
\text { entrepreneurial. Firms with } \\
\text { high EO achieve high } \\
\text { performance. }\end{array}$ \\
\hline 2011 & $\begin{array}{c}\text { Goodale et } \\
\text { al. }\end{array}$ & $\begin{array}{l}\text { Management } \\
\text { support } \\
\text { Autonomy } \\
\text { Rewards } \\
\text { Time } \\
\text { availability } \\
\text { Organizational } \\
\text { boundaries }\end{array}$ & Antecedent & $\begin{array}{l}\text { Innovation } \\
\text { performance }\end{array}$ & $\begin{array}{l}\text { Management support and } \\
\text { time availability are negatively } \\
\text { related to innovation when } \\
\text { moderated by risk control. } \\
\text { Organizational boundaries } \\
\text { relate positively to innovation } \\
\text { when moderated by risk } \\
\text { control. Time availability } \\
\text { negatively related to } \\
\text { innovation when moderated } \\
\text { by process control formality. }\end{array}$ \\
\hline 2011 & Li et al. & $\begin{array}{l}\text { Innovativeness } \\
\text { Proactiveness } \\
\text { Risk-taking }\end{array}$ & Moderator & $\begin{array}{l}\text { Knowledge } \\
\text { acquisition }\end{array}$ & $\begin{array}{l}\text { Distributor's EO positively } \\
\text { moderates the constructive } \\
\text { conflict-knowledge } \\
\text { acquisition relationship and } \\
\text { negatively moderates the } \\
\text { destructive conflict- } \\
\text { knowledge acquisition } \\
\text { relationship. Manufacturers } \\
\text { should work with distributors } \\
\text { with high levels of EO. }\end{array}$ \\
\hline 2011 & Paulraj & $\begin{array}{l}\text { Innovativeness } \\
\text { Proactiveness } \\
\text { Risk-taking }\end{array}$ & Antecedent & $\begin{array}{l}\text { Sustainable } \\
\text { supply } \\
\text { management } \\
\text { Sustainability } \\
\text { performance }\end{array}$ & $\begin{array}{l}\text { EO increases the adoption of } \\
\text { sustainable supply } \\
\text { management and } \\
\text { sustainability performance. }\end{array}$ \\
\hline 2007 & Das \& Joshi & $\begin{array}{l}\text { Innovativeness } \\
\text { Risk-taking } \\
\text { Autonomy }\end{array}$ & $\begin{array}{l}\text { Moderator } \\
\text { and } \\
\text { Outcome }\end{array}$ & $\begin{array}{c}\text { Process } \\
\text { innovativeness }\end{array}$ & $\begin{array}{l}\text { Differentiation and autonomy } \\
\text { are positively related to } \\
\text { process innovativeness. The } \\
\text { influence of differentiation on } \\
\text { process innovativeness is } \\
\text { moderated by autonomy, but } \\
\text { the influence is not } \\
\text { moderated by risk-taking. }\end{array}$ \\
\hline
\end{tabular}


INTERNATIONAL JOURNAL OF ENTREPRENEURIAL KNOWLEDGE

Issue 1, volume 9, ISSN 2336-2960 (Online)

www.ijek.org

\begin{tabular}{|c|c|c|c|c|c|}
\hline Year & Authors & $\begin{array}{c}\text { EO } \\
\text { Dimensions } \\
\end{array}$ & $\begin{array}{c}\text { EO } \\
\text { Used As }\end{array}$ & $\begin{array}{c}\text { Dependent } \\
\text { Variable }\end{array}$ & Findings \\
\hline 2007 & $\begin{array}{l}\text { Ireland \& } \\
\text { Webb }\end{array}$ & $\begin{array}{l}\text { Innovativeness } \\
\text { Proactiveness } \\
\text { Risk-taking } \\
\text { Autonomy } \\
\text { Aggressiveness }\end{array}$ & Outcome & $\begin{array}{c}\text { Cultural } \\
\text { competitiveness }\end{array}$ & $\begin{array}{l}\text { A balanced trust and power } \\
\text { climate creates cultural } \\
\text { competitiveness } \\
\text { (entrepreneurship and } \\
\text { learning) between companies. }\end{array}$ \\
\hline 2005 & $\begin{array}{c}\text { Jambulingam } \\
\text { et al. }\end{array}$ & $\begin{array}{l}\text { Innovativeness } \\
\text { Proactiveness } \\
\text { Autonomy } \\
\text { Aggressiveness } \\
\text { Risk-taking } \\
\text { Motivation }\end{array}$ & $\begin{array}{l}\text { Cluster } \\
\text { criteria }\end{array}$ & Typologies & $\begin{array}{l}\text { True entrepreneurs and low- } \\
\text { risk entrepreneurs achieve } \\
\text { high performance (i.e., } \\
\text { effectiveness, customer } \\
\text { orientation, growth } \\
\text { perception, and innovative } \\
\text { services). }\end{array}$ \\
\hline 2003 & $\begin{array}{c}\text { Brockman \& } \\
\text { Morgan }\end{array}$ & $\begin{array}{l}\text { Innovativeness } \\
\text { Proactiveness } \\
\text { Risk-taking }\end{array}$ & Antecedent & $\begin{array}{l}\text { Innovative } \\
\text { information }\end{array}$ & $\begin{array}{l}\text { EO is positively related to } \\
\text { innovative information } \\
\text { acquisition. Innovative } \\
\text { information acquisition is } \\
\text { associated with new product } \\
\text { innovativeness. }\end{array}$ \\
\hline
\end{tabular}

